\begin{tabular}{|l|l|l|l|l|l|}
\hline J. Tek. Ling & Vol. 12 & No. 1 & Hal. 43 - 53 & Jakarta, Januari 2011 & ISSN 1441-318X \\
\hline
\end{tabular}

\title{
PENGARUH RESIDU PESTISIDA TERHADAP POLA POPULASI BAKTERI DAN FUNGI TANAH DI RUMAHKACA
}

\author{
Nunik Sulistinah ${ }^{1}$, S. Antonius ${ }^{2}$ dan Maman Rahmansyah ${ }^{3}$ \\ 1,2,3 Bidang Mikrobiologi, Pusat Penelitian Biologi-LIPI \\ CSC, Jl. Raya Jakarta-Bogor Km 46, Cibinong 16911 \\ Email: listin_ar @yahoo.com
}

\begin{abstract}
Pesticide Residue was Affect Bacterial and Fungal Population in the Greenhouse Soil Condition. Bacterial and fungal inhabitants were examined through agriculture soil samples. Survival of microorganism in soil was important to evaluate the mineralize process. In the greenhouse experiment, bacterial and fungal population noticed as essential assessment in soil healing with long lasting pesticide (A-soil) after the soil treated with powdered rice straw as organic matter amendment, toxic degrading bacterial as inoculants, and the both of those mixed treatments. That residue implication also assessed to B-soil (as free pesticide soil) then revised with pesticides, and also treated as followed for A-soil. Potential degradation of indigenous microorganism examined all through as setting of control (B-soil) to recognize of its original population. Those of treatments evaluated through microbial survival along 12 weeks incubation in green house environment. Bacterial and fungal populations was affect to become fluctuated along with incubation period as due to the treatments. Bacterial inhabitant was considerably higher compared to fungal population. Correlations were significantly difference with bacterial $(p=0.6654)$ as well as fungal $(p=0.9029)$ population in A-soil evaluated to $B$-soil habitats since the mixed treatments present to both of the soil $(p 0.005=0.6310)$. Organic matter alteration and certain microbe input was needed in soil contain pesticide, because at the same time the survival of microbes possibly mineralized organic matter, as well as the pesticide residue.
\end{abstract}

Key words: bacteria, fungi, pesticide, organic matter, population.

\section{PENDAHULUAN}

\subsection{Latar Belakang}

Dalam mendukung hasil-hasil pertanian, penggunaan agrokimia belum dapat sepenuhnya ditinggalkan dalam aktivitas agronomi di Indonesia. Kegiatan pertanian organik memang telah mulai dirintis namun pada komoditas di lokasi tertentu masih tetap memerlukan sentuhan bahan kimia pupuk, herbisida, pestisida dan sejenisnya. Penggunaan bahan kimia tadi masih tetap menjadi pertimbangan sehubungan dengan efisiensi produksi. Penggunaaan pestisida tidak akan bermasalah sepanjang penggunaannya terkendali dan tepat, namun implikasi terhadap kehidupan mikroba tanah perlu diperhitungkan.

Tingkat kesuburan dalam suatu 
ekosisitem tanah di antaranya bergantung kepada mediasi populasi mikroba untuk mengkonversi bahan organik. Populasi mikroba tanah dapat menjadi indikator kesetabilan ketika tanah terkontaminasi pestisida $^{1}$. Bakteri dan fungi (cendawan) merupakan bagian dari komponen biogeosphere dan di antaranya berfungsi dalam proses mineralisasi untuk memelihara keseimbangan nutrisi tanah. Oleh karena itu keberadaan bakteri dan fungi di tanah dapat menjadi metode pendekatan selaku fungsi bioindikator berdasar kemampuan hidup dan aktivitas mikroflora tersebut ${ }^{2,3}$.

Residu pestisida kelompok organoklorin dapat terakumulasi di lapisan atas tanah sampai kedalaman $50 \mathrm{~cm}$ yang keberadaannya bisa menekan populasi mikroba heterotropik serta kelompok bakteri nitrifikasi ${ }^{4)}$. Pada beberapa koloni fungi tertentu ada yang memanfaatkan sumber karbon berasal dari residu pestisida ${ }^{5}$, 6). Fungi pada awalnya sensitif terhadap keberadaan pestisida namun kemudian dapat cepat menyesuaikan untuk melakukan metabolisme secara normal ${ }^{7)}$. Respon mikroba tanah terhadap pestisida dipengaruhi oleh komposisi kimianya. Newton et al. ${ }^{8)}$ menyatakan bahwa efek pestsida lebih nyata terhadap struktur komunitas dibandingkan terhadap aktivitas fisiologi mikroba.

Melalui penelitian ini telah dilakukan pengamatan pada populasi bakteri dan fungi di tanah yang mengandung residu pestisida. Populasi diamati pada tanah yang telah lama menerima asupan pestisida akibat aktivitas agronomi, kemudian dibandingkan dengan tanah yang seketika terkena pestisida. Pengamatan dilakukan di rumah kaca selama duabelas minggu inkubasi setelah perlakuan pestisida. Tujuannya adalah untuk melihat kondisi populasi bakteri dan fungsi yang memanfaatkan sumber karbon residu pestisida dan sumber organik lainnya, sehubungan dengan kemampuan proses metabolismenya selama inkubasi. Kemampuan hidup bakteri dan fungi di tanah berfungsi mendukung kestabilan transformasi bahan organik untuk menjadi bahan anorganik yang kemudian dibutuhkan oleh tumbuhan.

\section{BAHAN DAN METODE}

\subsection{Penyiapan sampel tanah dan bahan penelitian}

Sampel tanah diperoleh dari Stasiun Kebun Percobaan Hortikultur di Cipanas, Cianjur, Jawa Barat. Tanah dianalisa di Laboratorium Ekologi, Bidang Mikrobiologi, Pusat Penelitian Biologi LIPI. Tanah dikeringanginkan, disaring $(<2 \mathrm{~mm})$, dan selanjutnya dilakukan pengukuran terhadap $\mathrm{pH}(5,5-5,7)$, kadar air $(6,4-6,7 \%)$, kandungan kimia (N 0,2\%; C 2,7\%; Ca-Mg-K-Na masingmasing 12,5-1,4-0,5-0,2 $\mathrm{cmol}_{(+)} / \mathrm{kg} ; \mathrm{P}_{2} \mathrm{O}_{5}$ dan $\mathrm{K}_{2} \mathrm{O}$ masing-masing 91 dan $35 \mathrm{mg} / 100 \mathrm{~g}$ ), dan komposisi pasir-debu-liat (44-36-20\%).

Kelompok sampel Tanah-A (tanah pertanian) adalah yang mengandung residu pestisida, sedangkan kelompok Tanah-B (tanah kebun) merupakan tanah bebas pestisida dan kemudian diberi perlakuan pestisida. Insektisida dengan bahan dasar deltamethrin (Decis) dan fungisida probineb (Antracol) keduanya diberikankan pada takaran 11,3 g (perbandingan 1/1), untuk setiap $1000 \mathrm{~g}$ Tanah-B. Bahan organik berupa serbuk jerami padi (SJP) yang kemudian digunakan untuk memperkaya tanah dengan dosis $20 \mathrm{~g}$ per $1000 \mathrm{~g}$ tanah. Inokulan yang mengandung mikroba pendegradasi senyawa toksik (PST) yaitu terdiri dari isolate bakteri Pseudomonas $\mathrm{sp}$. dan fungi Flavobacterium sp. yang diperoleh dari koleksi kultur hasil penelitian sebelumnya. Inokulan disiapkan dengan menumbuhkan bakteri dan fungi di dalam media cair (nutrien-broth: $3 \mathrm{~g}$ beef extract, $5 \mathrm{~g}$ peptone, dan $1000 \mathrm{ml}$ aquadest) dan diinkubasikan sehingga mencapai kepadatan populasi masing-masing $10^{7} \mathrm{cfu}$ (bacterial colony forming unit) dan $26.10^{6} \mathrm{cfu}$ (fungal colony forming unit). Selanjutnya inokulan diberikan kepada setiap $1000 \mathrm{~g}$ tanah 
dengan dosis $20 \mathrm{ml}$ PST yang terdiri atas $10 \mathrm{ml}$ dari sediaan bakteri dan $10 \mathrm{ml}$ dari sediaan fungi.

\subsection{Perlakuan penelitian}

Setiap $1000 \mathrm{~g}$ sampel tanah dimasukkan ke dalam kantong plastik hitam (polybag), kemudian diberikan SJP dan PST sesuai perlakuan dengan menggunakan tiga ulangan (lihat Tabel-1). Seluruh sampel tanah (27 polybag) disimpan di rumah kaca dan diinkubasi selama 12 minggu. Setiap sampel tanah dipertahankan kelembabannya sebatas kapasitas lapang. Pengamatan populasi bakteri dan fungi dilakukan pada awal pengamatan $\left(M_{0}=2\right.$ jam setelah tanah memperoleh perlakuan) kemudian dilanjutkan pada minggu ke-2, 4, 6, 8, dan $12\left(\mathrm{M}_{12}\right)$.

\subsection{Penghitungan koloni mikroba}

Penghitungan koloni bakteri dan fungi mengacu kepada metode yang dikembangkan oleh Carvalhal et al. ${ }^{9}$. Penumbuhan bakteri dilakukan pada media nutrien-agar (3g beef extract, $5 \mathrm{~g}$ peptone, $15 \mathrm{~g}$ agar, dan $1000 \mathrm{ml}$ aquadest), sedangkan penghitungan fungi ditumbuhkan pada media malt-extract-agar (30g malt-extract, $5 \mathrm{~g}$ peptone, $15 \mathrm{~g}$ agar, dan $1000 \mathrm{ml}$ aquadest). Penghitungan populasi mikroba ditentukan dengan metode seri pengenceran. Pertumbuhan mikroba dipantau di bawah Magnified-Plate-Counter dan diamati selama $2 \times 24$ jam.

\subsection{Analisis data}

Nilai korelasi dan uji beda nyata dilakukan terhadap nilai rataan dari tiga ulangan pada seluruh sampel pengamatan untuk setiap perlakuan dengan mengacu kepada cara analisis Parker ${ }^{10)}$. Seluruh data dikalkulasi dengan menggunakan bantuan program StatView for Windows (Vertion 5.0.1).

\section{HASIL DAN PEMBAHASAN}

\subsection{Konfigurasi populasi}

Populasi bakteri terhitung lebih tinggi dari populasi fungi. Kepadatan bakteri berkisar antara $10^{6}$ sampai $10^{9} \mathrm{cfu}$, dan fungi antara $10^{4}$ sampai $10^{5} \mathrm{cfu}$ yang meliputi populasi pada Tanah-A dan Tanah-B, maupun kontrolnya (Gambar 1). Konfigurasi

Tabel 1. Penataan perlakuan

\begin{tabular}{|c|c|c|c|c|c|c|}
\hline No. & Perlakuan & $\begin{array}{l}\text { Tanah-A } \\
(1000 \mathrm{~g})\end{array}$ & $\begin{array}{l}\text { Tanah-B } \\
(1000 \mathrm{~g})\end{array}$ & $\begin{array}{c}\text { Decis \& } \\
\text { Antracol } \\
11,3 \mathrm{~g}\end{array}$ & $\begin{array}{c}\text { Bahan } \\
\text { Organik } \\
\text { (SJP) } 20 \mathrm{~g}\end{array}$ & $\begin{array}{c}\text { Inokulan } \\
\text { (PST) } \\
26.10^{6} \cdot \mathrm{m}^{\mathrm{l}-1}\end{array}$ \\
\hline 1. & Tanah-A & + & -- & -- & -- & -- \\
\hline 2. & Tanah-A + SJP & + & -- & -- & + & -- \\
\hline 3. & Tanah-A + PST & + & -- & -- & -- & + \\
\hline 4. & $\begin{array}{l}\text { Tanah-A + SJP \& } \\
\text { PST }\end{array}$ & + & -- & -- & + & + \\
\hline 5. & Tanah-B & -- & + & + & -- & -- \\
\hline 6. & Tanah-B + SJP & -- & + & + & + & -- \\
\hline 7. & Tanah-B + PST & -- & + & + & -- & + \\
\hline 8. & $\begin{array}{l}\text { Tanah-B + SJP \& } \\
\text { PST }\end{array}$ & -- & + & + & + & + \\
\hline 9. & $\begin{array}{l}\text { Kotrol (tanpa } \\
\text { pestisida) }\end{array}$ & -- & + & -- & -- & -- \\
\hline
\end{tabular}


populasi bakteri tertinggi pada pengamatan $\mathrm{M}_{0}$ dan populasi fungi terjadi pada masa inkubasi dua minggu $\left(\mathrm{M}_{2}\right)$. Kepadatan bakteri per gram tanah akan didapatkan lebih tinggi karena ukurannya lebih kecil dibanding kepadatan mikroba berfilamen seperti fungi dan aktinomisetes ${ }^{11}$. Bakteri dan fungi adalah mikroflora yang dapat menempati bagian struktur tanah yang terkecil dan dapat berinteraksi langsung dengan residu pestisida yang memasuki partikel tanah. Hasil penelitian pada tanah tercemar pestisida mempelihatkan adanya gangguan terhadap populasi mikroba yang diakibatkan oleh besarnya asupan 12) macam unsur kimia senyawa toksik ${ }^{13)}$, struktur diversitas jenis mikroflora tanah ${ }^{3)}$, dan keragaman respon individu spesies 14,15,16). Sedangkan faktor fisik yang ominan mempengaruhi perkembangan mikroflora dalam kaitannya dengan degradasi residu pestisida adalah tekstur tanah dan bahan organik yang terkandung ${ }^{13)}$.

Pemberian bahan organik dan mikroba pendegradasi senyawa toksik (Perlakuan-4) pada Tanah-B yang diberi pestisida menyebabkan populasi bakteri $\left(10^{8} \mathrm{cfu}\right)$ lebih tinggi dari populasi yang terdapat pada sampel Tanah-A maupun kontrolnya untuk masa pengamatan dua minggu. Hasil penamatan memberi asumsi bahwa bakteri yang terdapat pada inokulan mampu sinergi dengan mikroba asli tanah (indigenous) yang mampu berproliferasi setelah inkubasi dua minggu akibat penyertaan bahan organik jerami padi yang terjadi pada Tanah-B mengandung pestisida. Populasi fungi pada masa inkubasi minggu kedua terjadi meningkat pada Tanah-A dan juga Tanah-B. Peningkatan terjadi pada tanah yang mengandung cukup bahan organik, serta bahan organik yang diberi inokulan bakteri pendegradasi senyawa toksik.

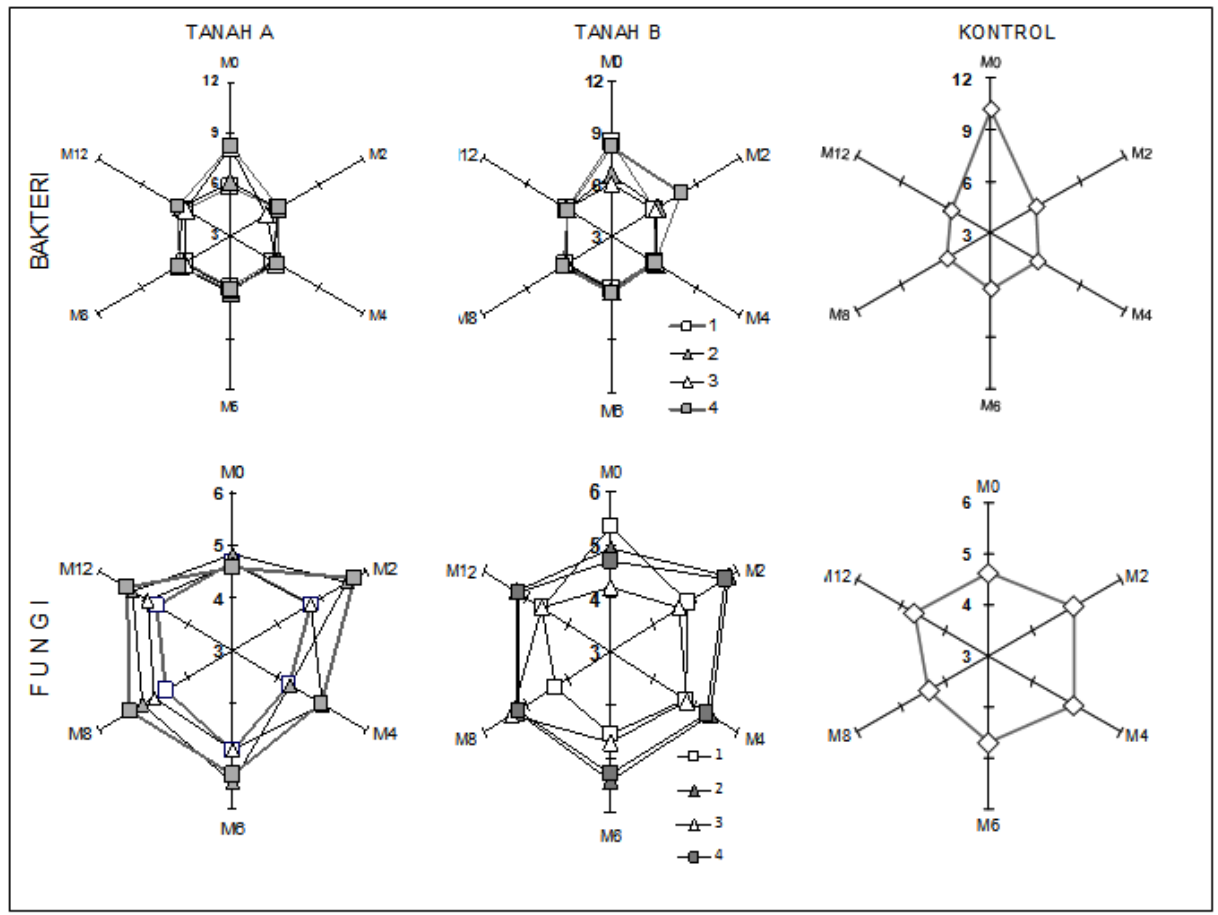

Gambar 1. Konfigurasi populasi bakteri dan fungi (log-x) pada hasil observasi 12 minggu (M0 sampai M12) inkubasi. Populasi pada tanah bebas pestisida ( ) dibandingkan terhadap hasil perlakuan karena penambahan SJP ( ), PST（）, dan SJP \& $\operatorname{PST}($ ) 
Dampak pestisida terhadap kehidupan mikroflora adalah bervariasi yang disebabkan karena perbedaan tipe tanah dan juga terkait dengan kompleksitas kelompok mikroflora yang terkandung di dalamnya ${ }^{17}$. Beberapa kelompok mikroba tertentu memiliki respon positif terhadap kehadiran pestisida karena dapat memanfaatkannya sebagai sumber karbon, namun sementara kelompok lainnya menjadi tidak dapat berkembang dan bahkan mungkin dalam kurun waktu yang lama akan tertekan oleh keberadaan pestisida yang akhirnya menjadi punah dari lingkungannya ${ }^{18,19}$.

\subsection{Uji signifikan untuk setiap populasi}

Pengamatan terhadap populasi mikroba dapat dilihat pada Tabel 2 (bakteri) dan Tabel 3 (fungi). Populasi bakteri pada Tanah-B menunjukkan adanya efek antar perlakuan yang nyata pada awal pengamatan dan 4 minggu pengamatan. Sementara itu, populasi bakteri pada Tanah-A berbeda nyata pada setiap perlakuan setelah masa inkubasi enam minggu.

Kepadatan fungi pada Tanah-A terpengaruh secara nyata karena perlakuan, dan perbedaan itu terlihat di dalam setiap perlakuan. Perbedaan mulai nampak pada minggu kedua dan keenam, dan semakin kuat perbedaannya akibat perlakuan pada pengamatan populasi minggu 8 sampai
12. Perbedaan yang nyata pada Tanah-B hanya terjadi pada masa inkubasi enam minggu, dan masih cukup signifikan terjadi pada pengamatan minggu ke delapan. Hasil telaahan Newton et al ${ }^{8)}$ menyatakan bahwa sintasnya kelompok mikroba pada lingkungan tanah tercemar pestisida merupakan suatu hasil penyaringan secara alamiah.

Asumsi keberadaan bakteri indigenous di antara tanah yang mendapatkan perlakuan PST terlihat pada hasil pengamatan pada kelompok Tanah-A maupun terhadap kelompok Tanah-B. Sing dan Walker ${ }^{20)}$ menyatakan pada hasil pengamatannya bahwa bakteri yang sintas karena mendapat perlakuan pestisida merupakan kelompok bakteri yang memang tidak terpengaruh kehidupannya oleh keberadaan pestisida tersebut. Sedangkan pada sisi lainnya, kelompok bakteri fungsional yang yang diberikan perlakuan inokulan PST akan hidup lebih sintas karena memanfaatkan residu pestisida yang menjadi bagian dari sistem metabolismenya. Dengan memperhatikan fenomena di atas maka keberadaan populasi mikroba yang hidup di lingkungan tanah yang tercemar pestisida menjadi penting dan berguna untuk mengevaluasi suatu pengaruh cemaran pestisida terhadap keberadaan mikroorganisme khususnya di lingkungan tanah pertanian.

Tabel 2. Hasil analisis uji beda nyata terhadap populasi bakteri. ( $\mathrm{S}$ menunjukkan nilai beda nyata karena perlakuan, sedangkan NS menunjukkan tidak beda nyata).

\begin{tabular}{|c|c|c|c|c|c|}
\hline Inkubasi & Perlakuan & $\mathrm{T}(\text { Tanah })^{1}$ & $T+S_{J} P^{2}$ & $\mathrm{~T}+\mathrm{PST}^{3}$ & $T+S J P \& P S T^{4}$ \\
\hline Tanah-A & $\mathrm{T}$ (Tanah) & $\Phi$ & NS & $S(p<0,0001)$ & $S(p<0,0001)$ \\
\hline \multirow[t]{3}{*}{0 minggu } & $T+$ SJP & & $\Phi$ & $S(p<0,0001)$ & $S(p<0,0001)$ \\
\hline & $\mathrm{T}+\mathrm{PST}$ & & & $\Phi$ & NS \\
\hline & $T+$ SJP \& PST & & & & $\Phi$ \\
\hline Tanah-B & $\mathrm{T}$ (Tanah) & $\Phi$ & $S(p<0,0001)$ & $S(p<0,0001)$ & $S(p=0,0033)$ \\
\hline \multirow[t]{3}{*}{0 minggu } & $T+S J P$ & & $\Phi$ & $S(p<0,0001)$ & $S(p<0,0001)$ \\
\hline & $T+P S T$ & & & $\Phi$ & $S(p<0,0001)$ \\
\hline & $T+$ SJP \& PST & & & & $\Phi$ \\
\hline Tanah-A & $\mathrm{T}$ (Tanah) & $\Phi$ & NS & $S(p=0,0004)$ & NS \\
\hline \multirow[t]{2}{*}{2 minggu } & $T+S J P$ & & $\Phi$ & $S(p=0,0002)$ & NS \\
\hline & $\mathrm{T}+\mathrm{PST}$ & & & $\Phi$ & $S(p<0,0001)$ \\
\hline
\end{tabular}




\begin{tabular}{|c|c|c|c|c|c|}
\hline & $T+S J P \& P S T$ & & & & $\Phi$ \\
\hline Tanah-B & $\mathrm{T}$ (Tanah) & $\Phi$ & $S(p<0,0001)$ & NS & $S(p<0,0001)$ \\
\hline \multirow[t]{3}{*}{2 minggu } & $\mathrm{T}+\mathrm{SJP}$ & & $\Phi$ & $S(p<0,0001)$ & $S(p<0,0001)$ \\
\hline & $\mathrm{T}+\mathrm{PST}$ & & & $\Phi$ & $S(p<0,0001)$ \\
\hline & $T+S J P \& P S T$ & & & & $\Phi$ \\
\hline Tanah-A & $\mathrm{T}$ (Tanah) & $\Phi$ & NS & $S(p=0,0009)$ & $S(p=0,0002)$ \\
\hline \multirow[t]{3}{*}{4 minggu } & $T+S J P$ & & $\Phi$ & $S(p=0,0039)$ & $S(p=0,0007)$ \\
\hline & $\mathrm{T}+\mathrm{PST}$ & & & $\Phi$ & NS \\
\hline & $T+$ SJP \& PST & & & & $\Phi$ \\
\hline Tanah-B & $\mathrm{T}($ Tanah $)$ & $\Phi$ & $S(p<0,0001)$ & $S(p=0,0002)$ & $S(p=0,0053)$ \\
\hline \multirow[t]{3}{*}{4 minggu } & $T+$ SJP & & $\Phi$ & NS & $S(p=0,0065)$ \\
\hline & $\mathrm{T}+\mathrm{PST}$ & & & $\Phi$ & $S(p=0,0304)$ \\
\hline & $T+$ SJP \& PST & & & & $\Phi$ \\
\hline Tanah-A & $\mathrm{T}$ (Tanah) & $\Phi$ & $S(p<0,0001)$ & $S(p=0,0407)$ & $S(p=0,0002)$ \\
\hline \multirow[t]{3}{*}{6 minggu } & $T+S J P$ & & $\Phi$ & $S(p<0,0001)$ & $S(p=0,0007)$ \\
\hline & $\mathrm{T}+\mathrm{PST}$ & & & $\Phi$ & $S(p=0,0036)$ \\
\hline & $T+$ SJP \& PST & & & & $\Phi$ \\
\hline Tanah-B & $\mathrm{T}$ (Tanah) & $\Phi$ & $\mathrm{S}(p=0,0002)$ & $S(p=0,0322)$ & $S(p<0,0001)$ \\
\hline \multirow[t]{3}{*}{6 minggu } & $T+S J P$ & & $\Phi$ & $S(p=0,0047)$ & NS \\
\hline & $\mathrm{T}+\mathrm{PST}$ & & & $\Phi$ & $S(p=0,0008)$ \\
\hline & $T+$ SJP \& PST & & & & $\Phi$ \\
\hline Tanah-A & $\mathrm{T}$ (Tanah) & $\Phi$ & $S(p<0,0001)$ & $S(p=0,0014)$ & $S(p<0,0001)$ \\
\hline \multirow[t]{3}{*}{8 minggu } & $T+S J P$ & & $\Phi$ & $S(p<0,0001)$ & NS \\
\hline & $\mathrm{T}+\mathrm{PST}$ & & & $\Phi$ & $S(p<0,0001)$ \\
\hline & $T+$ SJP \& PST & & & & $\Phi$ \\
\hline Tanah-B & $\mathrm{T}$ (Tanah) & $\Phi$ & NS & $S(p<0,0001)$ & $S(p<0,0001)$ \\
\hline \multirow[t]{3}{*}{8 minggu } & $T+S J P$ & & $\Phi$ & $S(p<0,0001)$ & $S(p<0,0001)$ \\
\hline & $\mathrm{T}+\mathrm{PST}$ & & & $\Phi$ & $S(p<0,0001)$ \\
\hline & $T+$ SJP \& PST & & & & $\Phi$ \\
\hline Tanah-A & $\mathrm{T}$ (Tanah) & $\Phi$ & $\mathrm{S}(p<0,0001)$ & NS & $S(p<0,0001)$ \\
\hline \multirow[t]{3}{*}{12 minggu } & $T+S J P$ & & $\Phi$ & $S(p<0,0001)$ & $S(p=0,0003)$ \\
\hline & $\mathrm{T}+\mathrm{PST}$ & & & $\Phi$ & $S(p<0,0001)$ \\
\hline & $T+$ SJP \& PST & & & & $\Phi$ \\
\hline Tanah-B & $\mathrm{T}($ Tanah $)$ & $\Phi$ & NS & NS & NS \\
\hline \multirow[t]{3}{*}{12 minggu } & $T+$ SJP & & $\Phi$ & NS & $S(p=0,0140)$ \\
\hline & $\mathrm{T}+\mathrm{PST}$ & & & $\Phi$ & $\mathrm{S}(p<0,0001)$ \\
\hline & $T+$ SJP \& PST & & & & $\Phi$ \\
\hline
\end{tabular}

1) Tanah tanpa "bahan organik" (SJP) dan tanpa "inokulan pendegradasi senyawa toksik" (PST)

2) Tanah + bahan organik

3) Tanah + inokulan pendegradasi senyawa toksik

4) Tanah diberi perlakuan keduanya 
Tabel 3. Hasil analisis uji beda nyata terhadap populasi fungi. (S menunjukkan nilai beda nyata karena perlakuan, sedangkan NS menunjukkan tidak beda nyata).

\begin{tabular}{|c|c|c|c|c|c|}
\hline Inkubasi & Perlakuan & $\mathrm{T}\left(\right.$ Tanah $^{1}{ }^{1}$ & $\mathrm{T}+\mathrm{SJP}^{2}$ & $\mathrm{~T}+\mathrm{PST}^{3}$ & $T+S J P \& P_{S T}{ }^{4}$ \\
\hline Tanah-A & $\mathrm{T}$ (Tanah) & $\Phi$ & $S(p=0,0191)$ & NS & NS \\
\hline \multirow[t]{3}{*}{0 minggu } & $T+S J P$ & & $\Phi$ & $S(p=0,0066)$ & $S(p=0,0008)$ \\
\hline & $\mathrm{T}+\mathrm{PST}$ & & & $\Phi$ & NS \\
\hline & $\mathrm{T}+$ SJP \& PST & & & & $\Phi$ \\
\hline Tanah-B & T (Tanah) & $\Phi$ & $S(p=0,0086)$ & NS & NS \\
\hline \multirow[t]{3}{*}{0 minggu } & $T+S J P$ & & $\Phi$ & $S(p=0,0250)$ & NS \\
\hline & $T+P S T$ & & & $\Phi$ & NS \\
\hline & $T+$ SJP \& PST & & & & $\Phi$ \\
\hline Tanah-A & $\mathrm{T}($ Tanah) & $\Phi$ & $S(p<0,0001)$ & NS & $S(p<0,0001)$ \\
\hline \multirow[t]{3}{*}{2 minggu } & $\mathrm{T}+\mathrm{SJP}$ & & $\Phi$ & $S(p<0,0001)$ & $S(p=0,0030)$ \\
\hline & $\mathrm{T}+\mathrm{PST}$ & & & $\Phi$ & $S(p<0,0001)$ \\
\hline & $\mathrm{T}+\mathrm{SJP} \& \mathrm{PST}$ & & & & $\Phi$ \\
\hline Tanah-B & $\mathrm{T}$ (Tanah) & $\Phi$ & NS & $\mathrm{S}(p=0,0003)$ & $S(p=0,0125)$ \\
\hline \multirow[t]{3}{*}{2 minggu } & $\mathrm{T}+\mathrm{SJP}$ & & $\Phi$ & $\mathrm{S}(p=0,0020)$ & NS \\
\hline & $\mathrm{T}+\mathrm{PST}$ & & & $\Phi$ & $S(p=0,0173)$ \\
\hline & $T+S J P \& P S T$ & & & & $\Phi$ \\
\hline Tanah-A & $\mathrm{T}$ (Tanah) & $\Phi$ & NS & $S(p=0,0001)$ & $S(p=0,0002)$ \\
\hline \multirow[t]{3}{*}{4 minggu } & $\mathrm{T}+\mathrm{SJP}$ & & $\Phi$ & $S(p=0,0002)$ & $S(p=0,0002)$ \\
\hline & $\mathrm{T}+\mathrm{PST}$ & & & $\Phi$ & NS \\
\hline & $\mathrm{T}+\mathrm{SJP} \& \mathrm{PST}$ & & & & $\Phi$ \\
\hline Tanah-B & $\mathrm{T}$ (Tanah) & $\Phi$ & $S(p<0,0001)$ & NS & $\mathrm{S}(p=0,0002)$ \\
\hline \multirow[t]{3}{*}{4 minggu } & $\mathrm{T}+\mathrm{SJP}$ & & $\Phi$ & $S(p=0,0001)$ & NS \\
\hline & $T+P S T$ & & & $\Phi$ & $S(p=0,0004)$ \\
\hline & $T+$ SJP \& PST & & & & $\Phi$ \\
\hline Tanah-A & $\mathrm{T}$ (Tanah) & $\Phi$ & $\mathrm{S}(p<0,0001)$ & NS & $S(p<0,0001)$ \\
\hline \multirow[t]{3}{*}{6 minggu } & $\mathrm{T}+\mathrm{SJP}$ & & $\Phi$ & $S(p<0,0001)$ & $S(p=0,0024)$ \\
\hline & $\mathrm{T}+\mathrm{PST}$ & & & $\Phi$ & $S(p<0,0001)$ \\
\hline & $T+$ SJP \& PST & & & & $\Phi$ \\
\hline Tanah-B & $\mathrm{T}$ (Tanah) & $\Phi$ & $S(p<0,0001)$ & $S(p=0,0208)$ & $S(p<0,0001)$ \\
\hline \multirow[t]{3}{*}{6 minggu } & $\mathrm{T}+\mathrm{SJP}$ & & $\Phi$ & $S(p<0,0001)$ & $S(p=0,0382)$ \\
\hline & $\mathrm{T}+\mathrm{PST}$ & & & $\Phi$ & $S(p<0,0001)$ \\
\hline & $T+$ SJP \& PST & & & & $\Phi$ \\
\hline Tanah-A & $\mathrm{T}($ Tanah) & $\Phi$ & $S(p<0,0001)$ & $S(p=0,0024)$ & $S(p<0,0001)$ \\
\hline \multirow[t]{3}{*}{8 minggu } & $\mathrm{T}+\mathrm{SJP}$ & & $\Phi$ & $S(p=0,0030)$ & $S(p<0,0001)$ \\
\hline & $\mathrm{T}+\mathrm{PST}$ & & & $\Phi$ & $S(p<0,0001)$ \\
\hline & $T+S J P \& P S T$ & & & & $\Phi$ \\
\hline
\end{tabular}




\begin{tabular}{|l|l|c|c|c|c|}
\hline Tanah-B & T (Tanah) & $\Phi$ & $\mathrm{S}(p<0,0001)$ & $\mathrm{S}(p<0,0001)$ & $\mathrm{S}(p<0,0001)$ \\
\hline 8 minggu & T + SJP & & $\Phi$ & $\mathrm{NS}$ & $\mathrm{NS}$ \\
\hline & T + PST & & & $\Phi$ & $\mathrm{S}(p=0,0160)$ \\
\hline & T + SJP \& PST & & & & $\Phi$ \\
\hline Tanah-A & T (Tanah) & $\Phi$ & $\mathrm{S}(p<0,0001)$ & $\mathrm{S}(p=0,0025)$ & $\mathrm{S}(p<0,0001)$ \\
\hline 12 minggu & T + SJP & & $\Phi$ & $\mathrm{S}(p<0,0001)$ & $\mathrm{S}(p=0,0364)$ \\
\hline & T + PST & & & $\Phi$ & $\mathrm{S}(p<0,0001)$ \\
\hline & T + SJP \& PST & & & & $\Phi$ \\
\hline Tanah-B & T (Tanah) & $\Phi$ & $\mathrm{S}(p<0,0001)$ & $\mathrm{NS}$ & $\mathrm{S}(p=0,0002)$ \\
\hline 12 minggu & T + SJP & & $\Phi$ & $\mathrm{S}(p<0,0001)$ & $\mathrm{NS}$ \\
\hline & T + PST & & & $\Phi$ & $\mathrm{S}(p<0,0001)$ \\
\hline & T + SJP \& PST & & & & $\Phi$ \\
\hline
\end{tabular}

1) Tanah tanpa "bahan organik" (SJP) dan tanpa "inokulan pendegradasi senyawa toksik" (PST)

2) Tanah + bahan organik

3) Tanah + inokulan pendegradasi senyawa toksik

4) Tanah diberi perlakuan keduanya

\subsection{Fluktuasi populasi selama inkubasi}

Fluktuasi yang diamati diperhitungkan terhadap kepadatan mikroba yang diperbandingkan terhadap tanah yang tidak meneriam perlakuan (Gambar 2). Perbedaan kerapatan populasi juga dilihat secara keseluruhan berdasar nilai korelasi (Tabel 4). Kedua data tersebut mempertegas adanya pengaruh dari setiap perlakuan maupun efek dari kelompok tanah yang terjadi pada Tanah-A maupun Tanah-B.

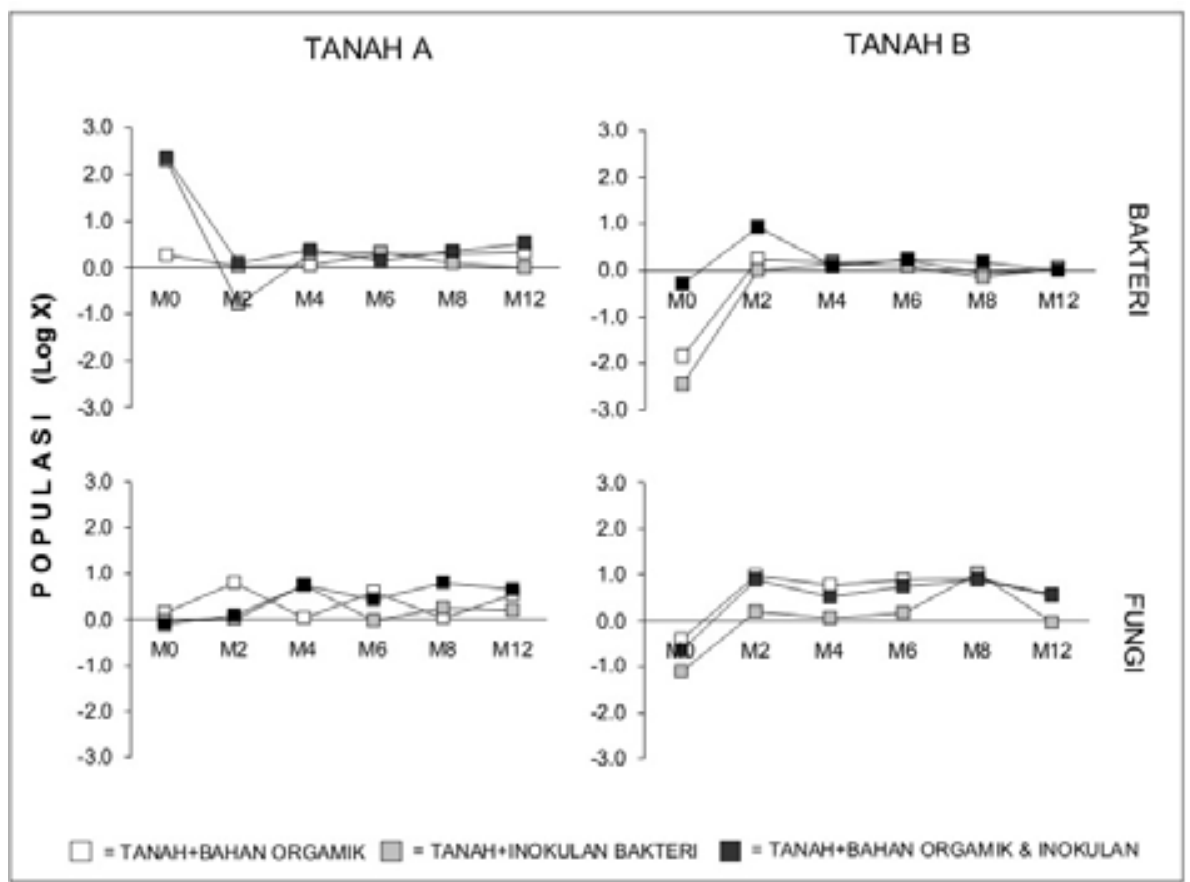

Gambar 2. Populasi mikroba berfluktuasi selama 12 minggu pengamatan. 
Tabel 4. Nilai korelasi di antara populasi mikroba yang tumbuh di Tanah-A dengan yang tumbuh di Tanah- $B(\alpha<0,005$ dengan $n=18$ adalah $p=0,631)$.

\begin{tabular}{|c|c|c|c|c|}
\hline PERLAKUAN: & $\operatorname{Tanah}(\mathrm{T})^{1}$ & $T+S J P^{2}$ & $\mathrm{~T}+\mathrm{PST}^{3}$ & $T+S J P \& P S T{ }^{4}$ \\
\hline Bakteri: & $-0,4277$ & $-0,1288$ & $-0,4031$ & $0,6654(\mathrm{~S})$ \\
\hline Fungi: & 0,0787 & 0,4955 & 0,2855 & $0,9029(\mathrm{~S})$ \\
\hline
\end{tabular}

1) tanah tanpa "bahan organik" (SJP) dan tanpa "inokulan bakteri pendegradasi nitrat" (PST)

2) tanah + bahan organik

3) tanah + inokulan bakteri pendegradasi nitrat

4) tanah diberi perlakuan keduanya

Dampak pemberian pestisida pada Tanah-B mempengaruhi populasi fungi pada awal pengamatan. Populasi bakteri pada Tanah-A saat awal pengamatan memperlihatkan sebaliknya, yang terjadi pada tanah yang mendapat perlakuan PST dan perlakuan SJP \& PST. Populasi fungi pada tanah yang sama terjadi sebaliknya terjadi pada semua perlakuan. Penelitian Cycon dan Piotrowska-Seget 3) mendapatkan bahwa isolat bakteri dari tanah tercemar pestisida memperlihatkan respon fisiologis berbeda ketika dilakukan uji ulang di laboratorium dengan berbagai jenis pestisida berbeda. Kompleksitas lingkungan tanah menimbulkan perbedaan nyata pada setiap respon biokimiawi dari jenis bakteri ketika ditumbuhkan pada lingkungan yang lebih terkontrol di laboratorium, sebagaimana terekspresikan melalui performa pertumbuhan yang baik karena mampu melakukan metabolisme lebih sempurna terhadap pestisida sebagai sumber karbon. Tekanan lingkungan terhadap bakteri pendegradasi senyawa toksik (PST) yang digunakan sebagai perlakuan pada penelitian ini tidak selalu efektif mendegradasi senyawa toksik pestisida menjadi nutrisi tanah karena dihadapkan dengan kondisi lingkungan yang kurang mendukungnya. Keberadaan senyawa senobiotik (senyawa toksik pestisida) menyebabkan reaksi metabolik yang berbeda di antara bakteri dan fungi ketika mendapatkan asupan pestisida sebagai perlakuan, yang diekspresikan dengan adanya fluktuasi pada setiap perlakuan selama rentang inkubasi tanah sampel penelitian.

\section{KESIMPULAN}

- Populasi bakteri lebih tinggi dari fungi pada tanah yang terkondisikan mengandung insektisida deltamethrin dan fungisida probineb

- Pemberian bahan organik berefek signifikan pada populasi fungi di tanah yang mengandung pestisida.

- Inokulan-bakteri-pendegradasi-senyawatoksik pada awal pengamatan sampai dua minggu inkubasi mengalami kenaikan sebagai ekspresi sintasnya inokulan pada tanah tercemar pestisida.

- Populasi bakteri dan fungi di tanah yang mengandung pestisida (perlakuan pada Tanah-B) pada awalnya terhambat, namun kemudian mampu melakukan peningkatan proliferasi pada periode berikutnya, dan kembali stabil sampai akhir masa inkubasi selama pengamatan.

- Penambahan bahan organik terhadap tanah tercemar pestisida bermanfaat untuk mendukung populasi mikroba yang kemudian efektif memineralisasi residu pestisida menjadi nutrisi tanah.

\section{UCAPAN TERIMA KASIH}

Penelitian didanai oleh proyek kerjasama Pusat Penelitian Biologi-LIPI dengan Gwangju Institute Science and Technology, Korea. Pada kesempatan ini kami menyampaikan terima kasih kepada Balai Penelitian Hortikultura, Departemen Pertanian, di Cipanas, Cianjur atas perijinan dalam menggunakan lahan maupun penggunaan sampel tanah sehingga 
pengamatan dapat dilaksanakan. Ucapan terima kasih disampaikan pula kepada rekan sejawat, khususnya kepada Dra. Sri Purwaningsih, atas segala dukungan dari semua rekan dari sejak awal penelitian sampai terwujudnya tulisan.

\section{DAFTAR PUSTAKA}

1. Brookes, P.C. 1995. The use of microbial parameters in monitoring soil pollution by heavy metals. Biol. Fertil. Soil. 19:269279.

2. Cycon, M. and Z. Piotrowska-Seget. 2007. Effect of selected pesticides on soil miroflora involved in organic matter and nitrogen transformations : Post experiment. Polish J. Ecol. 55(2): 207-220.

3. Cycon, M. and Z. Piotrowska-Seget. 2009. Changes in bacterial diversity and community structure following pesticides addition to soil estimated by cultivation technique. Ecotoxicology 18:632-642.

4. Ahmed, M.T., S.M.M. Ismail and S.S. Mabrouk. 1998. Residues of some chlorinated hydrocarbon pesticides in rain water, soil and ground water, and their influence on some soil microorganisms. Env. Int. 24 (5-6): 665-670.

5. Jenkinson, D.S. 1976. The effect of biocidal treatments on metabolism in soil. A method for measuring soil biomas. Soil Biol. Biochem. 8(3):209-213.

6. Nunez, A.E., A. Cabalero and J. Romas. 2001. Boilogical degradation of 2,4.6-trinitrotoluene. Microb. Mol. Bio. Rev. 65(3): 335-352.

7. Mandic, L., D. Dukic and S. Dordevic. 2005. Soil fungi as indicators of pesticide soil pollution. Proc. Nat. Sci, Matica Srpska Novi Sad.109: 97-102.

8. Newton, Z., N.Z. Lupwayi, K.N. Harker, L.M. Dosdall, T.K. Turkington, R.E. Blackshaw, J.T. O'Donovan, H.A. Cárcamo, J.K. Otani and G.W. Clayton. 2009. Changes in functional structure of soil bacterial communities due to fungicide and insecticide applications in canola. Agric. Eco. Env,130 (3-4) : 109114.

9. Carvalhal, M.L.C., M.S. Oliveira and F. Alterthum. 1991. An economical and time saving alternative to the most-probablenumber method for the enumeration of microorganisms. J. Microbiol. Methods, $14: 165-170$

10. Parker, RE.1979. Introductory Statistics for Biology. Studies in Biology No.43. Edward Arnold Ltd. London.

11. Alexander, M. 1977. Introduction to Soil microbiology, 2nd ed. John Wiley \& Sons, New York.

12. Sengupta, D., M.W. Aktar, S. Purkait and M. Ganguly. 2009. Impact of quinalphos on microbial biomass and activities in tropical clay loam soil. Elec. J. Env. Agric. Food Chem. 8(11):1127-1135.

13. Avidano, L., E. Gamalero, G.P. Cossa and E. Carraro. 2005. Charecterization of soil health in an Italian polluted site by using microorganism as bioindicators. Appl. Soil Ecol. 30:21-33.

14. Chen S-K., C.A. Edwards and S. Subler. 2001. Effects of the fungicides benomyl, captan and chlorothalonil on soil microbial activity and nitrogen dynamics in laboratory incubations. Soil Biol. Biochem. 33:1971-1980.

15. Kools, S.A.E., M. van Roovert, C.A.M. van Gestel, N.M. van Straalen. 2005. Glyphosate degradation as a soil health indicator for heavy metal polluted soils. Soil Biol. Biochem. 37:1303-1307.

16. Ratcliff, A.W., M.D. Busse and C.J. Shestak. 2006. Changes in microbial community structure following herbicide (glyphosate) addition to forest soils. Appl. Soil Ecol. 34:114-124.

17. Lipthay, J.R., K. Johnsen, H-J. Albrechtsen, P. Rosenberg, J. Aamand. 2004. Bacterial diversity and community structure of a subsurface aquifer exposed to realistic low herbicide concentrations. FEMS Mic. Ecol. 49:59-69.

18. Taiwo, L.B. and B.A. Oso. 1997. The influence of some pesticides on soil 
microbial flora in relation to changes in nutrient level, rock phosphate solubilization and $P$ release under laboratory conditions. Agric. Eco. Env. 65:59-68.

19. Das, A.C., A. Chakravarty, G. Sen, P. Sukul and D. Mukherjee. 2005. A comparative study on the dissipation and microbial metabolism of organophosphate and carbamate insecticides in orchaqualf and fluvaquent soils of West Bengal. Chemosphere 58:579-584.

20. Singh, B. and A. Walker. 2006. Microbial degradation of organophosphorus compounds. FEMS Micro. Rev. 30:428471. 